\title{
Promjene u sustavu poreza na dodanu vrijednost
}

\author{
DANIJELA KULIŠ Institut za javne financije
}

\begin{abstract}
Na sjednici Hrvatskog sabora I7. veljače 20I2. donesen je Zakon o izmjenama i dopunama Zakona o porezu na dodanu vrijednost (PDV). I bez oznake spisa "po hitnom postupku" brzina kojom je postupak okončan (od najave promjene Zakona krajem 2OII. do procedure Vlade i Sabora te stupanja na snagu I. ožujka), sama po sebi ukazuje na hitnost. U paketu porezne reforme našle su se i izmjene i dopune zakona o porezu na dohodak, dobiti i doprinosima. Učinke izmjena poreznih zakona snose svi - od javnog i gospodarskog sektora, do građana. Budući da se radi o ozbiljnim promjenama donesenim u tako kratkom, ali i kriznom vremenu, vrijedi promotriti jesu li se dovoljno analizirali i sagledali svi učinci promjena. Donošenje Državnog proračuna za 2012., podbačaj proračunskih prihoda i porast rashoda u razdoblju od 2008.-Io., fiskalna neravnoteža, rast deficita ijavnog duga, dovoljno su opravdani razlozi za poduzimanje nužnih fiskalnih mjera za konsolidiranje ukupnih državnih financija. U ovome radu riječ je o promjenama koje nas očekuju na području oporezivanja PDV-om.
\end{abstract}

\section{PROMJENE U SUSTAVU PDV-a}

Povećanje opće stope PDV-a nije popularna mjera, ali uz istodobne promjene $u$ oporezivanju dohotka (povećanje osobnog odbitka), smanjenje stopa doprinosa za zdravstveno osiguranje i proširenje obuhvata proizvoda koji se oporezuju sniženom stopom PDV-a, donekle će se ublažiti učinci opterećenja PDV-om.

U nastavku slijedi analiza navedenih promjena PDV-a.

\section{PROMJENE STOPA PDV-a}

U općoj gospodarskoj i fiskalnoj krizi koja potresa ne samo zemlje EU-a "porezne intervencije" često počivaju na po-

\footnotetext{
Izmjene i dopune Zakona o PDV-u obuhvaćaju:

- povećanje opće stope s 23 na 25\%;

- uvođenje snižene stope od Io\% na jestiva ulja i masti, biljnog i životinjskog podrijetla, dječju hranu i prerađenu hranu na bazi žitarica za dojenčad i malu djecu, isporuku vode, osim vode koja se stavlja na tržište u bocama ili u drugoj ambalaži i bijeli šećer od trske i šećerne repe;

- ograničenje odbitka pretporeza za nabavui održavanje plovila, zrakoplova, osobnih automobila i drugih sredstava za osobni prijevoz;

- ograničenje odbitka pretporeza za nabavu dobara i usluga za potrebe reprezentacije;

- povećenje praga za ulazak u sustav PDV-a;

- izmjene kaznenih odredbi.
}

većanju poreznih stopa kojima je svrha punjenje proračuna i smanjenje deficita. Unutar zemalja EU-a trenutno u tome vodi Mađarska ${ }^{\mathrm{x}}$ kja je povećala stopu s 25 na $27 \%$. Tijekom 20I2. povećanju stopa priklonili su se i Cipar, Češka, Irska, Ujedinjeno kraljevstvo, a tijekom ove ili sljedećih godina najavljuju ih i Bugarska, Francuska, Italija, Litva i Poljska. Može se zaključiti da se radi o uobičajenom instrumentu porezne politike kako bi se povećali porezni prihodi. Čak je i Europska komisija, uz predlaganje Europskog proračuna za razdoblje 20I4.-20., u lipnju 2OII. predložila uvođenje PDV-a od I\% na razini EU-a koji bi se umjesto iz udjela u nacionalnom PDV- $\mathrm{u}^{2}$ - izravno nametnuo poreznim obveznicima zemalja članica. Budućnost

I International VAT Service. http://www.tmf-vat.com/vat.html 2 Stopa je o,3\% nacionalnih prihoda od PDV-a, a primjenjuje se na osnovicu koja ne smije iznositi više od 50\% BNP-a. Primjenjuju se i privremene snižene stope za razdoblje od 2007.-I3. (o,225\% za Austriju, 0,15\% za Njemačku i o,I\% za Nizozemsku i Švedsku). 
ovog prijedloga je vrlo upitna ineizvjesna, a rasprava o njemu potrajat će do kraja 2012.

Kao što se moglo i očekivati u Hrvatskoj su najveću pozornost ekonomskih stručnjaka ali i javnosti izazvale najavljene promjene u sustavu PDV-a, posebice povećanje stope s 23 na $25 \%$. Kako bi se donekle ublažio povećani porezni teret, proširuje se obuhvat proizvoda koji će se oporezivati sniženom stopom od Io\%.

\section{POVEĆANJE OPĆE STOPE PDV-a}

Sudionici u poreznom sustavu dvije su zainteresirane (ne nužno suprotstavljene) strane. S jedne su porezne vlasti, a s druge porezni obveznici koji snose teret oporezivanja. Porezne vlasti povećanim porezom nastoje prikupiti dodatne prihode, dok porezni obveznici podmiruju zakonom propisane poreze, ali snose i posljedice poreznih promjena (povećanje cijena, smanjenje potrošnje i sl.). Kada se radi o porezima na potrošnju (PDV i trošarine), čiji je udio u proračunu RH gotovo 60\%, a obuhvaćaju i najveći broj poreznih obveznika, i najmanja promjena izaziva višestruke učinke.

Procjenjuje se da bi se povećanjem stope PDV-a za 2 postotna boda prihodi povećali s planiranih 39,3 $\mathrm{mlrd}$. u 2 OII. na 40,5 mlrd. u 2012., odnosno za 1,2 mlrd. ili 3,1\%. ${ }^{3}$ Visina porezne stope utječe na proračunske prihode, ali i na količine i cijene dobara i usluga, a posredno i na dohotke, potrošnju, konkurentnost na tržištu te životni standard građana.

\section{Tablica I.}

Porezni prihodi u Hrvatskoj u razdoblju 2008.-I2.

\begin{tabular}{|c|c|c|c|c|c|}
\hline & 2008. & 2009. & 2010. & $\begin{array}{l}\text { 2OII. } \\
\text { (plan) }\end{array}$ & $\begin{array}{l}\text { Proračun } \\
2012 .\end{array}$ \\
\hline $\begin{array}{l}\text { Ukupni porezni } \\
\text { prihodi Državnog } \\
\text { proračuna (bez } \\
\text { doprinosa, } \\
\text { u mil. kuna) }\end{array}$ & II5.773 & IIO. 258 & I07.466 & IO7.052 & IO8.649 \\
\hline $\begin{array}{l}\text { Prihodi od PDV-a } \\
\text { (u mil. kuna) }\end{array}$ & $4 \mathrm{I} .308$ & 37.050 & 37.689 & $39.3 I 4$ & 40.522 \\
\hline $\begin{array}{l}\text { Udio prihoda od } \\
\text { PDV-a u ukupnim } \\
\text { poreznim } \\
\text { prihodima }(\mathrm{u} \%)\end{array}$ & 35,68 & 33,60 & 35,07 & 36,72 & 37,30 \\
\hline
\end{tabular}

Izvor: Ministarstvo financija RH (20I2); Hrvatski sabor (2OI2).

\section{POVEǴANJE STOPE - POVEĆANJE POREZNIH PRIHODA?}

Može li povećanje stope PDV-a samo po sebi osigurati veće prihode? Od I. kolovoza 2009. povećana je stopa s 22 na $23 \%$, a porezni prihodi u kolovozu bili su manji od onih $u$

3 U medijima se, vjerojatno prema Smjernicama za izradu proračuna za 2OI2., spominje povećanje od 2,5 mlrd. kn, no prema Proračunu riječ je o $\mathrm{I}, 2 \mathrm{mlrd}$. $\mathrm{kn}$. srpnju. Tek u III. kvartalu prihodi su u odnosu na II. kvartal povećani za II,7\% (ne treba zanemariti sezonski utjecaj), a u IV. kvartalu bili su I,5\% manji nego u prethodnom. Ukupni prihodi od PDV-a u 2009. bili su gotovo IO\% manji nego u 2008. U Godišnjaku Ministarstva financija za 2009. smanjenje prihoda obrazlaže se padom gospodarske aktivnostiu 2009., posebice smanjenjenjem osobne potrošnje. Dakle, povećanje stope nije samo po sebi dovelo do povećanja prihoda.

U Smjernicama za izradu proračuna za 20I2. (Ministarstvo financija RH, 20I2) daje se procjena financijskih učinaka do kojih će doći promjenom visine stopa. "Povećanje opće stope poreza na dodanu vrijednost za dva postotna boda predstavlja dodatni prihod državnom proračunu od oko 3 milijarde kuna na godišnjoj razini. Snižavanje stope poreza na dodanu vrijednost s 23 na IO\% za ulja i masti umanjuje prihode za oko 220 milijuna kuna godišnje, za dječju hranu oko 75 milijuna kuna i za opskrbu vodom I6o milijuna kuna. Kombinirani godišnji efekt svih predloženih izmjena u sustavu poreza na dodanu vrijednost povećava prihode proračuna od oko 2,5 milijardi kuna.” U prijedlogu Državnog proračuna za 20I2., zbog promjena $u$ sustavu PDV-a predviđeno je povećanje prihoda za I,2 mlrd. kuna, dakle I,3 mlrd. kuna manje nego što je planirano Smjernicama.

Sve navedeno pokazuje kako je nesigurno planiranje prihoda od promjene stopa PDV-a jer na njih, osim stopa utječe niz faktora.

\section{POVEǴANJE STOPE: VIŠE GIJENE - MANJA POTROŠNJA?}

Intuitivno se dade zaključiti da će se povećanjem poreza povećati i cijena proizvoda i usluga na koje se nameće porez, premda ne treba zanemariti činjenicu da na formiranje cijena utječe i niz drugih čimbenika (odnosi na tržištu, konkurentnost, trgovačke marže itd).

Jednostavan bi izračun bio da se ubrani porezni prihodi uz ostale nepromjenjene okolnosti - povećaju za postotno povećanja stope (tj. 8,7\%). Ekonomija, međutim, nije tako jednostavna matematika. Ministar financija prilično je optimistično ustvrdio "da ne postoji niti jedan razlog zbog kojega bi povećanje PDV-a moglo utjecati na rast cijena i pri tome računa na poduzetnički i trgovački fair play"(Vresnik, 20I2). Teško je očekivati da će proizvođači i trgovci na sebe preuzeti porezni teret, te da ga neće prevaliti na krajnje potrošače. Realnija je izjava, B. Grčića ekonomskog stratega Vlade, "da bi cijene mogle doživjeti korekciju, vrlo blagu, ne više od I,4\%”(Vresnik, 20I2).

Povećanje cijena ne mora nužno biti posljedica povećanja poreznih stopa. U odnosu na 20Io. kada nije bilo povećanja poreznih stopa, potrošačke cijene u 2OII. porasle su za 
2,3\% (DZS, 2OI2). Najveći porast od 22,3\% zabilježen je kod tekućih goriva te alkoholnih pića i duhana $6,8 \%$ (utjecaj trošarina). U skupini prehrambenih proizvoda cijene su porasle 3,5\% (prednjače ulja i masti sa I6,I\%, a slijede kruh i žitarice s 5,4\%). Bez obzira na uzroke, povećanje cijena izaziva promjene $u$ ponašanju potrošača, proizvođača $i$ trgovaca. Potrošači više neće htjeti ili moći kupovati neke proizvode, smanjit će se potrošnja, što može - unatoč povećanju stope - rezultirati smanjenjem poreznih prihoda. Smanjenje potrošnje ovisi i o elastičnosti potražnje. Ako je potražnja za nekim dobrom neelastična, većim se poreznim opterećenjem ne mijenja količina prodaje (Urban, 20II). Cjenovna elastičnost uglavnom je niska kod osnovnih prehrambenih proizvoda i kućanskih potrepština (i kod proizvoda koji se oporezuju trošarinama), pa se očekuje da promjena cijene neće bitno smanjiti potrošnju tih proizvoda. Međutim s porastom cijena pada potražnja za proizvodima koji nisu dio nužnih životnih potreba kao što su npr. određena hrana, odjeća, obuća, bezalkoholna pića, pokućstvo, oprema za kuću, aparati zajedno s uslugama prijevoza, telekomunikacija, održavanja, popravaka. Hoće li se građani zbog povećanog poreza, a time i cijena, djelomično ili u potpunosti odreći potrošnje tih dobara ili usluga?

Ukoliko funkcioniraju zakoni tržišta (ponude i potražnje), te ako postoji konkurencija, zbog mogućeg se pada prodaje, te prekogranične kupovine u susjednim zemljama (niži porezi u Sloveniji, 20\% i BiH, $17 \%$ ) može očekivati da će neki domaći proizvođači i trgovci smanjiti svoje marže kako bi povećali prodaju.

\section{UTJECAJ NA ŽIVOTNI STANDARD}

Za razliku od poreza na dohodak koji je progresivan (ljudi s višim dohotkom plaćaju veće novčane iznose poreza), PDV je regresivan. Za građane s nižim dohocima udio izdataka za nabavu dobara u dohotku je znatno veći nego za građane s višim primanjima (Urban, 2OII). Zbog toga postoji bojazan da će povećanje stope PDV-a najviše ugroziti građane s najnižim prihodima. Procjena je predsjednika Nezavisnih hrvatskih sindikata ${ }^{4}$ da bi mjesečni izdaci porasli oko Ioo kuna ili I,46\%, ali bi to donekle trebalo biti ublaženo promjenama u porezu na dohodak za najniže dohodovne kategorije i sniženjem stope PDV-a određenih proizvoda.

Regresivno bi djelovanje PDV-a valjalo ispravljati sustavom socijalnih transfera ili progresivnim djelovanjem ostalih poreznih oblika. Umjesto sniženih stopa PDV-a na dječju hranu, masti, jestiva ulja, šećer, vodu i sl., koje bi trebale kompenzirati porast životnih troškova zbog povećanja PDV-a s 23 na 25\%, bolje je osigurati izravnu pomoć

4 “Jutarnji list”, I2. veljače 2012. najsiromašnijim građanimai povećati osnovni odbitakporeza na dohodak (Ott, 20I2).

\section{UVOĐENJE SNIŽENE STOPE ZA NOVU SKUPINU PROIZVODA}

Idealan sustav PDV-a je onaj s jednom stopom, širokom osnovicom i malim brojem izuzeća (Kesner-Škreb, 1999). Iako su prednosti jedne stope PDV-a ekonomski nedvosmislene, najviše se rasprava obično vodi upravo oko broja i visine porezne stope. U EU jedino Danska primjenjuje jednu stopu (25\%) dok ostale zemlje EU-a imaju od 2 do čak 4 stope (Francuska, Irska, Luksemburg). Kao većina zemalja Hrvatska sada ima tri stope (dvije i nulta stopa), a budući da se do pristupanja EU-u ukida nulta stopa, imat će ih dvije (opću i sniženu). Kako zakonodavstvo EU-a dopušta primjenu najviše dvije snižene stope, moguće je da će i u Hrvatskoj biti pritisaka za uvođenjem još jedne snižene stope.

Sadašnjim izmjenama Zakona određeni su novi proizvodi koji će se umjesto s dosadašnjih 23\% oporezivati sniženom stopom od IO\%. Od I. siječnja 20I3. proširit će se i na usluge u turizmu i ugostiteljstvu koje će se također oporezivati stopom od Io\% (usluge pripremanja hrane i obavljanje usluga prehrane u ugostiteljskim objektima te pripremanje i usluživanje bezalkoholnih pića i napitaka, vina i piva u tim objektima, sukladno posebnim propisima).

\section{PREDNOSTI I NEDOSTAGI OPOREZIVANJA SNIŽENOM STOPOM}

Porezna izuzeća, snižene i nulte stope uvode se radi smanjivanja regresivnog učinka PDV-a. Međutim, primjena sniženih stopa otvara nekoliko pitanja.

Prvo, tko ima koristi od sniženih stopa? Premda se uvode prvenstveno zbog siromašnijih građana, od njih imaju koristi i građani s višim primanjima.

Drugo je pitanje: što će se dogoditi s cijenama? Hoće li se one smanjiti primjenom niže porezne stope? Moguća su dva scenarija (Ott i sur., 1996).

Prvi predviđa da će svi proizvođači i trgovci u lancu dodane vrijednosti, nakon promjene visine stope PDV-a točno obračunavati PDV. To znači da će proizvodi koji se danas oporezuju stopom od $23 \%$ poskupiti točno za razliku između te stope i nove stope od 25\%. Proizvodi koji se danas oporezuju stopom od 23\%, a od I. ožujka stopom od IO\%, pojeftiniti će za tu razliku.

Drugi scenarij predviđa da će neki proizvođači i trgovci iskoristiti promjene stopa za neopravdano povećanje cijena (čak i minimalno), odnosno da neće sniziti cijene točno za 
razliku smanjenja poreza. Problem se otvara i u prerađivačkom lancu proizvoda na koje se primjenjuje snižena stopa. Hoće li nakon sniženja stope za šećer proizvođači koji koriste šećer u proizvodnom procesu (npr. za konditorske proizvode, sokove, sirupe i dr.) ili ulje (npr. za majonezu, gotovu hranu) sniziti cijene tih proizvoda?

I napokon postavlja se pitanje točnog definiranja proizvoda koji se oporezuju sniženom stopom (Kesner-Škreb, 1999). Što se točno smatra dječjom hranom za malu djecu? Kako će se razlikovati npr. keksi ili voćni sokovi namjenjeni maloj djeci od onih koji to nisu?

Uvođenje sniženih stopa PDV-a za određene proizvode je loše jer komplicira i poskupljuje porezni sustav, odnosno sustav ubiranja i kontrole poreza, što rezultira i slabijom učinkovitošću poreznog sustava.

\section{PRAG ZA ULAZAK U SUSTAV PDV-a}

Premda je visina praga za ulazak u sustav važno pitanje pri oporezivanju PDV-om, u ekonomskoj teoriji pa čak i u praksi relativno je mali broj istraživanja koja su se time podrobnije bavila. Jedno od takvih pokušava utvrditi optimalnu visinu praga za ulazak u sustav (Keen i Mintz, 2004.), analizirajući utjecaj visine praga na porezne prihode i troškove oporezivanja. Previsok prag može - zbog neuključivanja određenog broja poreznih obveznika u sustav PDV-a - dovesti do gubitka poreznih prihoda. S druge strane, prenizak prag znatno opterećuje poreznu upravu i porezne obveznike i povećava troškove oporezivanja. Problem postaje još složeniji uzme li se u obzir i narušavanje tržišnog natjecanja koje proizlazi iz različitog poreznog položaja poduzetnika koji su u sustavu i onih koji to nisu. Kako bi se oslobodili tereta velikog broja poreznih obveznika koji imaju mali promet, porezne uprave u većini razvijenih zemalja odlučuju se za viši prag.

Premda je odredbama Direktive Vijeća 2006/II2/EZ propisana minimalna visina praga (5.0oo eura), u pregovorima o pristupanju EU-u postignuta je mogućnost povećanja praga s 85.000 kuna (nije se mijenjao od 1999.) do 230.000 kuna. Ova je visina praga ugrađena u Zakon s primjenom od I. siječnja 20I3. Poduzetnicima s manjim obujmom poslovanja trebala bi pojednostaviti, a time i pojeftiniti poslovanje jer neće biti obvezni utvrđivati obvezu poreza niti podnositi zakonom propisane obrasce. Obveznici koji i dalje žele ostati obveznici PDV-a ne moraju se ispisati iz registra, ali su obvezni idućih pet kalendarskih godina ostati u sustavu.

Ovim se izmjenama i dopunama povećava - s 300.000 na $800.000 \mathrm{kn}$ - i iznos koji određuje je li porezni obveznik tromjesečni ili mjesečni obveznik. "Mali poduzetnik" će u tomslučajuumjestodvanaest, podnositisamočetiriobras- ca tijekom godine, što će smanjiti administriranje i obveznika i porezne uprave.

\section{OGRANIǦENJE PRAVA NA ODBITAK PRETPOREZA \\ OGRANIČENJE ODBITKA PRETPOREZA ZA PRIJEVOZNA SREDSTAVA}

Dosadašnje 70\%-tno odbijanje pretporeza za nabavu, najam i održavanje osobnih automobila i drugih prijevoznih sredstava otvaralo je mogućnosti izbjegavanja porezne obveze te umanjenje poreznih prihoda. Samo porezni obveznici koji su nabavljali osobne automobile i prijevozna sredstva iznad 400.ooo kuna nisu mogli koristiti odbitak pretporeza. Porezna je uprava uočila nedostake i netransparentnost u provođenju ovih odredbi, pa se izmjenama Zakona od I. ožujka 20I2. propisuje potpuno ograničenje odbitka pretporeza za nabavu i najam plovila namijenjenih za razonodu, zrakoplova, osobnih automobila i drugih sredstava za osobni prijevoz, uključujući nabavu svih dobara i usluga u vezi s tim dobrima.

Navedene se odredbe ne primjenjuju ukoliko se radi o plovilima i zrakoplovima za prijevoz putnika i dobara, za iznajmljivanja ili za daljnju prodaju, te ako se radi o osobnim automobilima i drugim prijevoznim sredstvima za osobni prijevoz koja se koriste za obuku vozača, testiranje vozila, servisnu službu, prijevoz putnika i dobara, prijevoz umrlih, iznajmljivanje ili za daljnju prodaju.

Ova će promjena zasigurno utjecati na smanjenje prodaje automobila čemu će doprinijeti i povećanje opće stope PDV-a. Nepriznavanje odbitka pretporeza održavanja prijevoznog sredstva (popravci, novi dijelovi, cestarine, gorivo) poduzetnicima će povećati troškove, ali će moći kao trošak iskazati ukupan iznos računa (s PDV-om).

\section{OGRANIČENJE ODBITKA PRETPOREZA ZA REPREZENTAGIJU}

Do izmjena Zakona moguće je bilo odbiti 30\% pretporeza troškova reprezentacije. Novim odredbama propisuje ograničenje odbitka pretporeza za nabavu dobara i usluga za potrebe reprezentacije. Reprezentacijom se smatraju izdaci za ugošćivanje i darivanje poslovnih partnera, plaćanje njihovih izdataka za odmor, sport i razonodu, za najam automobila, plovila, zrakoplova, kuća za odmor i sl.

Kad se ta dobra kasnije isporučuju, a za njih pri nabavi nije mogao biti odbijen pretporez, propisano je oslobođenje od plaćanja PDV-a.

\section{FISKALNI UǦINGI ODBITKA PRETPOREZA}

Porezna uprava nastoji ograničenjem prava na odbitak poreza suzbiti izbjegavanje plaćanja poreza za dobra koja se koriste u privatne svrhe, a nabavljaju preko pravne osobe, te tako onemogućiti da obveznici svoje privatne račune "pokrivaju" kao poslovne izdatke. 
Ministarstvo financija procjenjuje da će godišnji učinak ukidanja pretporeza na troškove reprezentacije i troškove automobila za razdoblje od Io mjeseci ove godine iznositi 550 milijuna kuna.

\section{PROMJENA KAZNENIH ODREDBI}

Propisane kazne za prekršaje poreznih obveznika utvrđene su u iznosima od I.ooo do 500.ooo kuna. Izmjenjenim Zakonom povećava se i kaznena odgovornost za osobe odgovorne za vođenje određenih poslova poreznog obveznika. Kazne su povećane s dosadašnjih Io.ooo kuna na 40.00o kuna, odnosno s 20.000 na 50.00o kuna.

\section{DODATNI UČINGI PROMJENA U SUSTAVU PDV-a}

Svaka porezna promjena donosi stanovite praktične poteškoće koje je teško izmjeriti ili novčano iskazati. Svi će poduzetnici i trgovci od I. ožujka 20I2. u svojim knjigama i računima morati iskazivati promet s novom stopom poreza. Sve blagajne i cjenici, kao i kalkulacije proizvođača moraju se prilagoditi novoj stopi. Treba prilagoditi i računovodstvene programe i tiskati nove obrasce. Neki će trgovci morati mjenjati cijene desetaka tisuća artikala. Sve su to dodatni troškovi oporezivanja koje donose promjene u sustavu. I poreznim obveznicima i poreznoj upravi promjena stopa i uvođenje i proširivanje obuhvata sniženim stopama povećati će obim poslova.

\section{ZAKLJUǦAK}

Hrvatska danas nije usamljen primjer zemlje opterećene gospodarskim, fiskalnim, dužničkim, korupcijskim i socijalnim problemima. Kako pronaći rješenje, za kojim instrumentima posegnuti kako bi se ti problemi prevladali? U pitanju fiskalne stabilnosti, rješavanju deficita i javnog duga jednako je važno poduzeti mjere i na prihodnoj i na rashodnoj strani proračuna. Prihodna se strana u najvećem djelu oslanja na porezne prihode. Svaka promjena $u$ poreznom sustavu utječe na javni sektor, gospodarstvo i građane, pa je nužno pripremiti analize ekonomskih učinaka i pratiti njihovo ostvarenje u budućnosti. Koliko god analize bile temeljite i detaljne neke je vrijednosti teško procijenjivati u nestabilnim gospodarskim okolnostima.

Procjene promjena visine stopa PDV-a trebale bi donijeti rast prihoda, uz pretpostavku da neće doći do smanjenja potrošnje i gospodarskih aktivnosti. Povećanjem stope porasti će i cijene proizvoda i usluga što može ugroziti životni standard građana. Snižavanje stope za neke osnovne životne namirnice - ako trgovci i proizvođači zaista snize cijene tih proizvoda - trebalo bi ublažiti negativne učinke na standard građana. Ipak umjesto korištenja sniženih stopa bolje je poduzimati mjere na rashodnoj strani proračuna socijalnim transferima najugroženijim skupinama građana kao i povećati osnovni osobni odbitak u oporezivanju dohotka.

Povećanje visine praga za ulazak u sustav PDV-a i povećanje iznosa za prelazak obveznika na tromjesečni obračun smanjit će troškove oporezivanja i poreznih obveznika i porezne administracije. Budući da se radi o promjeni koja stupa na snagu I. siječnja 2013. dovoljno je vremena za analize i procjene učinaka na proračunske prihode.

Uzroci gubitaka proračunskih prihoda mogu biti legalni i nelagalni. Legalni su kada zakonske odredbe omogućuju izbjegavanje ili utaju porezne obveze, a nelegalni proizlaze iz nepoštivanja zakonskih odredbi, kao što su neplaćanje poreza ili siva ekonomija. Odluka o ukidanju odbitka pretporeza za nabavu, održavanje ili najam prijevoznih sredstava te odbitka za reprezentaciju promjena je koja će uvesti transparentniju primjenu Zakona o PDV-u te smanjiti mogućnosti poreznih utaja. Mnogo veći problem leži u nenaplaćenim poreznim prihodima, odnosno dugovima koji su već dosegli enormni iznos od 42 mlrd. kuna od čega Vlada očekuje da bi mogla naplatiti 25,8 mlrd. kuna.

Planirani deficit u sljedećoj godini iznosi 9,9 mlrd. kuna, što je četvrtina nenaplaćenih poreznih prihoda. Je li Vlada kadra i u mogućnosti naplatiti barem dio ovog duga koji se već godinama kumulira?

Efikasno ubiranje poreza, stabilan i transparentan porezni sustav, pravedan raspored poreznog tereta uz stabilan gospodarski rast i povećanje zaposlenosti najvažniji su preduvjeti fiskalne konsolidacije i rješavanja fiskalne neravnoteže.

\section{LITERATURA}

Blažić, H., 2004. "Troškovi oporezivanja u Hrvatskoj: troškovi poreznih obveznika i troškovi poreznih vlasti”. Financijska teorija i praksa, 28 (3), 27I-29I.

DZS, 20II. Priopćenje: Indeks potrošačkih cijena u prosincu 2OII, broj I3.I.I/I2. Zagreb: Državni zavod za statistiku.

European Commission, 20II. A budget for Europe 2020. COM(2OII) 500 final. Brussles, 29.6. 20II. Dostupno na: [http://ec.europa.eu/budget/library/biblio/documents/ fin_fwkI420/MFF_COM-2OII-50O_Part_I_en.pdf].

Hrvatski sabor, 2012. Državni proračun Republike Hrvatske za 2012. godinu. Dostupno na: [http://www.sabor. $\mathrm{hr} /$ Default.aspx?art=46372].

Keen, M. i Mintz, J., 2004. "The optimal treshold for a value-added tax“. Journal of Public Economics, 88, 559-576

Kesner-škreb, M., 1999. “Deset razloga u korist jedinstvene stope poreza na dodanu vrijednost". Newsletter, br. 2. Dostupno na: [http://www.ijf.hr/newsletter/2.pdf]. 
Kuliš, D., 2009. Analiza učinaka promjene visine praga za ulazak u sustav PDV-a. Projekt izrađen u Institutu za javne financije za potrebe Ministarstva financija RH.

Ministarstvo financija RH, 2009. Godišnje izvješće Ministarstva financija za 2009. godinu. Zagreb: Ministarstvo financija.

Ministarstvo financija RH, 20II. Mjesečni statistički prikaz Ministarstva financija. Dostupno na: [http:// www.mfin.hr/adminmax/docs/I93\%20-\%2OListopad.pdf].

Ministarstvo financija RH, 2012. Prijedlog mjera i smjernice za izradu proračuna za 20I2. godinu. Dostupno na: [http://www.vlada.hr/hr/naslovnica/sjednice_i_odluke_vlade_rh/2OI2/5_sjednica_vlade_re-
publike_hrvatske/5_oI/(view_online)/I\#documentpreview].

Ott, K., 2012. "O poreznim promjenama i novom proračunu”. Banka, I8 (3), 6-7.

Ott, K. (i sur.), 1996. "Analiza fiskalnog sustava RH pri uvođenju poreza na dodanu vrijednost”. Financijska teorija i praksa, 20 (2), 129-258.

Urban, I., 20II. "Raspodjela poreznog opterećenja u Hrvatskoj”. Newsletter, br. 58. Dostupno na: [http://www. ijf.hr/newsletter/58.pdf].

Vresnik, V., 2012. "Još dva tjedna do poreznog udara. Je li vrijeme za veliki spasilački šoping?” Jutarnji list, I2. veljače 2012. 